\title{
Gloso-faringo-laringo-esofagitis cáustica fatal por ingestión de desatascador líquido comercial (hidróxido sódico al 47,8\%).
}

Fatal caustic pharyngo-laryngo-esophagitis by ingestion of commercial unblocker liquid ( $\mathrm{NaOH} 47,8 \%)$.

F. Repetto y cols.

Cuad Med Forense 2000; 21:92

Varón de 79 años con antecedentes de patología respiratoria crónica e intentos previos de suicidio. Es hallado fallecido en el domicilio con lesiones corrosivas de color negruzco en ambas comisuras bucales. En el examen interno se aprecia la fuerte coloración oscura de la mucosa lingual, faríngea, esofágica y laríngea, así como el fundus gástrico. Se remite para análisis químico un envase plástico con liquido incoloro de $\mathrm{pH}$ 13, que por espectrometría de emisión de plasma se identificó la presencia de sodio en elevadas concentraciones.

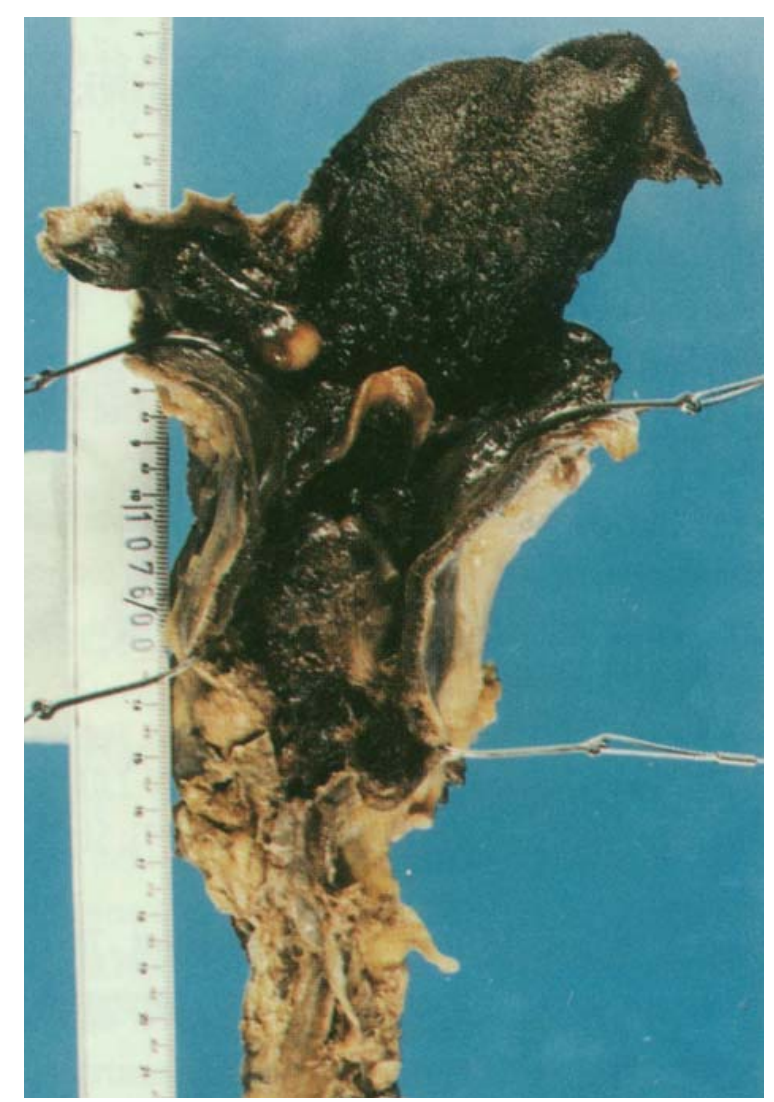

Figura 1.- Pieza glosolaríngea donde se observa la intensa coloración negruzca de la mucosa. 